\title{
アメリカ・カナダ・ヨーロッパの獣医学教育の現況 (III)
}

藤本 㭌*1) 笹本修司*2)

\section{1. アメリカにおける獣医学教育}

\section{3）アメリカ獣医師 会 (AVMA)（シカゴ）}

欧米に和ける獣医師制度抢よび獣医事情については, すでに農林水産省衛生課の松山 茂氏が調查され, アメ リカについても獣医師制度を報じている（家畜衛生週 報, No. 1529, 412,1978). われわれは今回アメリカではカ リフォルニア大学 (既設) とウイスコンシン大学 (新設) の 2 獣医学部の実態を視察した（前報 I, II）が，アメ リカ獣医師会 (AVMA) では日本の文部省視学委員会の ような権限をもって, 全米の獣医科大学の研究・教育の 発展向上のための指導を行っているので, それを含め全 米の獣医界の動向が把握できればと思い，AVMA を訪 れた.

AVMA では，獣医科大学の評価・認定といら上述の 重要業務のほか, 獣医師国家試験, 専門医制度および各 種の免許認定業務, 獣医保健衛生技術の情報収集やサー ビス, さらに J. Am. Vet. Med. Assoc. と Am. J. Vet.
Res. 2 誌の発行などの業務を行っている.それらの 2, 3 について概略を報告する。

(1) アメリカにおける獣医師の活躍の現況 : 今日, 全 米の獣医師総数は約 35,000 名で, その活躍職域は広い が，獣医師の $75 \%$ が個人開業 (private practice) であ る. その他の $25 \%$ が大学や研究所の職員, 州や地方官 庁の職員, 軍の獣医師あるいは企業（産業）に従事して いる獣医師などである（表 1)。これに対し，わが国では 獣医師総数が約 25,000 名で, 個人開業が $25 \%$ にすぎ ず，他は国家公務員 $3.4 \%$ ，都道府県職員 $35 \%$ ，市町村 職員 $7.5 \%$, 民間団体 $26 \%$ ，およびその他となっている (表 2 ). 臨床に従事していると考兄られる獣医師数は総 数の $36 \%$ 程度である. 個人開業がアメリカとはまった 〈逆の関係になっているのが実態である.アメリカのみ ならずカナダおよびョーロッパでも獣医師の大半が個人 開業あるいは臨床に従事して抢り，わが国の場合と大き な相違点となっている.これが日本と外国との獣医学教 育のあり方の差となって現れているょらで，欧米では実

表1 フォリカの獣医師の職域分布（1981 年調べ）

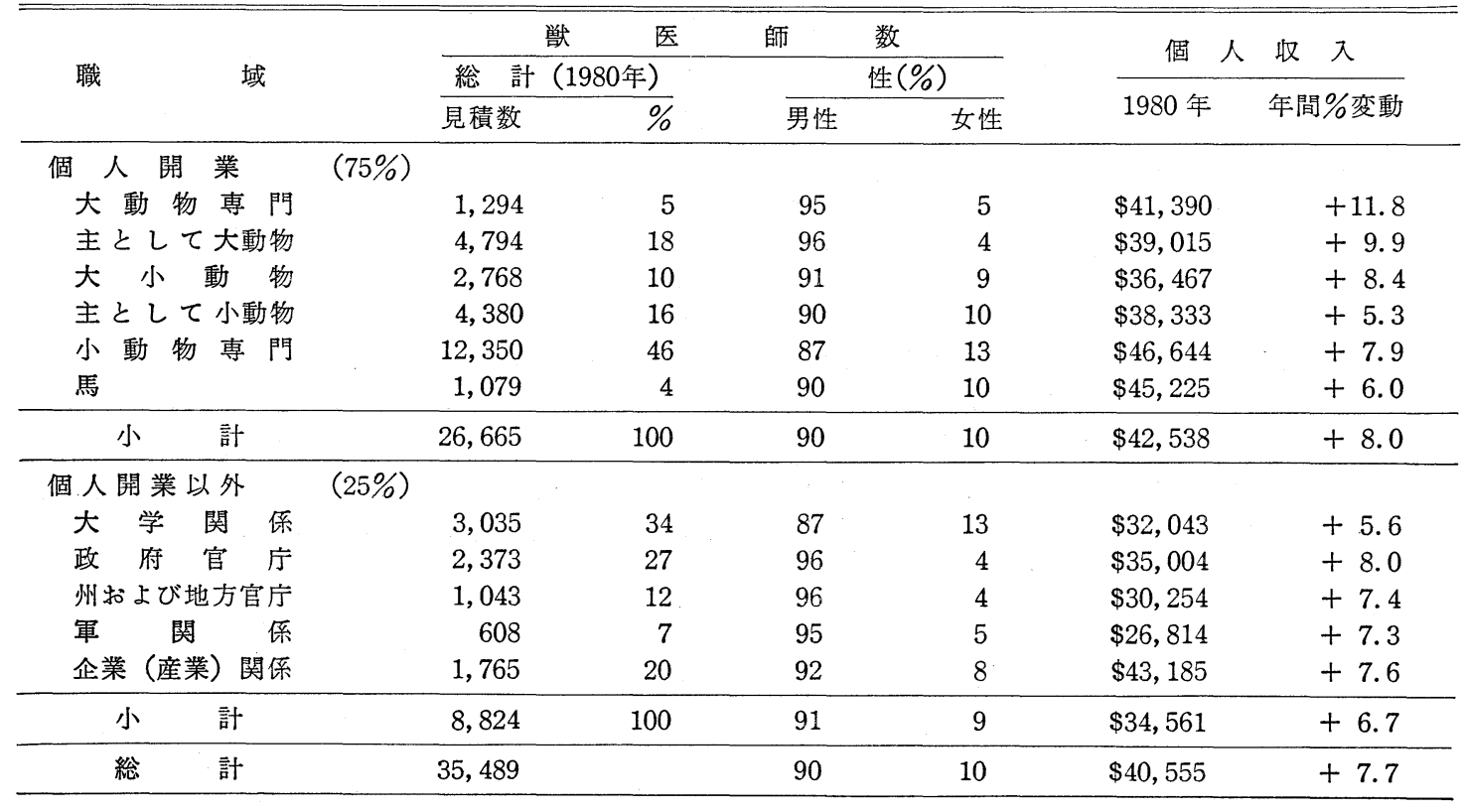

*1) 北海道大学獣医学部（札幌市北区北 18 条西 9 丁目）

*2) 東京農工大学農学部（東京都府中市幸町 3-5-8)

日獣会誌 $36 \quad 681 \sim 685 \quad$ (1983) 
資

表 2 日本の獣医師の職域分布

\begin{tabular}{|c|c|c|}
\hline \multirow{3}{*}{ 職 } & \multirow{2}{*}{\multicolumn{2}{|c|}{$\begin{array}{c}\text { 獣 医 師 数 } \\
\text { 総計 }(1979 \text { 年農林水産省調ベ) }\end{array}$}} \\
\hline & & \\
\hline & 見積数 & $\%$ \\
\hline \\
\hline 大 動 物 臨 㦿 & 2,249 & 39 \\
\hline 小 動 物 臨 床 & 3,429 & 60 \\
\hline その他 & 66 & 1 \\
\hline 小 計 & 5,744 & 100 \\
\hline \multicolumn{3}{|l|}{ 個人開業以外（75\%） } \\
\hline 国家公務員 & 791 & 4.5 \\
\hline 都道府県職員 & 8,040 & 47 \\
\hline 市町 村 職 員 & 1,728 & 10 \\
\hline 民 間 団 体 & 6,090 & 35 \\
\hline そ の 他 & 636 & 3.5 \\
\hline 小 & 17,285 & 100 \\
\hline 獣医事従事者 & 23,029 & \\
\hline 届 出 者 総 数 & 24,585 & \\
\hline
\end{tabular}

表 3 アメリカに拈ける獣医科大学登録学生数 （1980～1981年）

\begin{tabular}{|c|c|c|c|}
\hline \multicolumn{2}{|c|}{ 性 } & 学生数 & $\%$ \\
\hline 男 & 性 & 5,139 & 63 \\
\hline 女 & 性 & 3,014 & 37 \\
\hline 総 & 計 & 8,153 & 100 \\
\hline
\end{tabular}

表 4 アメリカ拈よびカナダの獣医科大学登録

\begin{tabular}{|c|c|c|c|}
\hline \multicolumn{2}{|c|}{ 学生数 } & \multicolumn{2}{|c|}{ （1981～1982年） } \\
\hline & アメリカ & カナダ & 計 \\
\hline 学 生 総 数 & 8,369 & 1,017 & 9,386 \\
\hline 女子学生 数 & $\begin{array}{c}3,571 \\
(43 \%)\end{array}$ & $\begin{array}{r}268 \\
(26 \%)\end{array}$ & $\begin{array}{r}3,839 \\
(41 \%)\end{array}$ \\
\hline 入学女子学生数 & 1,100 & 72 & 1,172 \\
\hline
\end{tabular}

表 5 アメリカおよびカナダの大学院生およびイン ターンならびにレジデント数（1981１982年）

\begin{tabular}{crccccr}
\hline & M.S. & Ph.D. & $\begin{array}{c}\text { インタ } \\
\text { ーン }\end{array}$ & $\begin{array}{l}\text { レジデ } \\
\text { ソド }\end{array}$ & 総 計 \\
\hline DVM & 510 & 319 & 101 & 200 & 1,130 \\
non-DVM & 483 & 305 & & & 788 \\
\hline 総 & 計 & 993 & 624 & 101 & 200 & 1,918 \\
\hline
\end{tabular}

地教育（臨床）飞重点が抒かれている.

最近，世界的傾向として女性獣医師が增兄つつあるが， 獣医師総数としてはアメリカでは, 男性 90\% に対し女性 10\%で必ずしも多くはない. 主として小動物臨床や大学 などに勤務している者が多い。しかし，学生に和ける女 性の割合をみると，1980１981 年で泩全学生の 37\% を
料

（表 3 ），1981～1982 年では 43\%（表4）を女子学生が 占め次第譜加している. 学校によっては女子学生が50 \%以上を占めるところもある。

獣医師の活躍職域としての臨床部門の内訳では, 小動 物臨床啍門が $52 \%$ と一番高い比率を占めている. つい で，小動物臨床を主とする者が $18 \%$ ，大動物臨床を主 とする者が $15 \%$ ，各種動物を扱う者が $8 \%$ ，大動物と馬 を対象にしている者が 7\% となっている(1979 年調べ).

日本の場合，年間 1,000 名が国家試験に合格し，300 名の獣医師が死亡している. 結局, 年間 700 名の獣医師 が増えていることになる．産業動物（大動物臨床）の獣 医師の平均年齢は 60 歳で, 最高齢者は 92 歳というの が現況であり，産業動物獣医師の高龄化が大きな社会問 題となっている.

(2) アメリカにおける獣医師国家試験制度 : 前述のご とく,アメリカで注約 35,000 名の獣医師の中で $75 \%$ の 約 26,000 名が臨床部門で活躍している. 各獣医科大学 (獣医学部) を卒業すると DVM (Doctor of Veterinary Medicine) の称号が与兄られる。しかし，これだけでは 家畜診療を行らことはできない。診療を行うには獣医師 免許証が必要である。そのために，AVMA の獣医師国 家試験委員会 (National Board Examination CommitteeNBEC) の指導下の獣医師国家試験（National Board Examination for Veterinary Medical Licensing-NBE) を受けなければならない。

NBEC は民間団体の専門試験サービス (Professional Examination Service=PES) の協力のもとに NBEを実施 する.

試験科目は次の上うな 3 部門からなっている.

Part I Preclinical Sciences（基礎科目，144問）：解 剖学, 生理学, 病的過程, 原因学, 薬理学, 中毒学㧧 び免疫学.

Part II その他の実技領域（36問）：公衆衛生，予防 医学拉よび諸法規.

Part III 臨床科学 (180問): 診断学, 治療学, 内科 学, 外科学就よび家畜繁殖学.

NBE では心血管系, 内分泌, 胃腸, 血液, リンパ, 皮 膚, 筋肉軀幹, 神経, 呼吸器, 特殊感覚特よび泌尿生殖 器を扱っている. 動物は犬, 猫, 牛, 豚, 羊, 山羊, 家 禽, 馬特よびその他の動物（水生動物, 実験 動物, 人 体，外来ならびに動物園動物扝よび野生動物）をも対象 としている。

NBE は 1 日で行う. 午前中 3.5 時間で Part I および

Part II を, 午後 3.5 時間で Part III を行う.

これに合格した者が州の獣医師免許試験を受けること となる。これを State Licensing Board という。いわゆ る実地試験で，州によりそれぞれ程度内容を異にしてい る.㐫る州で合格しても，他州で合格するとは限らない。 
表 6 アメリカおよびカナダの登録学生数（学校・学年別 1981〜1982 年）

\begin{tabular}{|c|c|c|c|c|c|c|}
\hline 獣医 & 科 大 & 1 年次 & 2 年次 & 3 年次 & 4 年次 & 計 \\
\hline \multirow{2}{*}{\multicolumn{2}{|c|}{$\begin{array}{l}\text { Auburn University } \\
\text { } \text { California, University of }\end{array}$}} & 115 & 114 & 115 & 113 & 457 \\
\hline & & 129 & 126 & 128 & 133 & 516 \\
\hline \multicolumn{2}{|c|}{ Colorado State University } & 139 & 136 & 138 & 135 & 548 \\
\hline \multicolumn{2}{|c|}{ Cornell University } & 80 & 80 & 80 & 78 & 318 \\
\hline \multicolumn{2}{|c|}{ Florida, University of } & 80 & 80 & 79 & 80 & 319 \\
\hline \multicolumn{2}{|c|}{ Georgia, University of } & 86 & 87 & 87 & 89 & 349 \\
\hline \multicolumn{2}{|c|}{ Illinois, University of } & 84 & 89 & 91 & 86 & 350 \\
\hline \multicolumn{2}{|c|}{ Iowa State University } & 122 & 118 & 121 & 122 & 483 \\
\hline \multicolumn{2}{|c|}{ Kansas State University } & 105 & 104 & 103 & 101 & 413 \\
\hline \multicolumn{2}{|c|}{ Louisiana State University } & 80 & 77 & 76 & 79 & 312 \\
\hline \multicolumn{2}{|c|}{ Michigan State University } & 100 & 120 & 115 & 105 & 440 \\
\hline \multicolumn{2}{|c|}{ Minnesota, University of } & 80 & 78 & 80 & 77 & 315 \\
\hline \multicolumn{2}{|c|}{ Mississippi State University } & 31 & 29 & 30 & 33 & 123 \\
\hline \multicolumn{2}{|c|}{ Missouri, University of } & 76 & 75 & 75 & 74 & 300 \\
\hline \multicolumn{2}{|c|}{ North Carolina State University } & 40 & & & & 40 \\
\hline \multicolumn{2}{|c|}{ Ohio State University } & 141 & 136 & 136 & 140 & 553 \\
\hline \multicolumn{2}{|c|}{ Oklahoma State University } & 70 & 68 & 70 & 68 & 276 \\
\hline \multicolumn{2}{|c|}{ Oregon State University } & 36 & & & & 36 \\
\hline \multicolumn{2}{|c|}{ Purdue University } & 72 & 72 & 71 & 76 & 291 \\
\hline \multicolumn{2}{|c|}{ Pennsylvania, University of } & 112 & 111 & 107 & 99 & 429 \\
\hline \multicolumn{2}{|c|}{ Tennessee, University of } & 60 & 58 & 81 & & 199 \\
\hline \multicolumn{2}{|c|}{ Texas A\&M University } & 138 & 144 & 75 & 74 & 431 \\
\hline \multicolumn{2}{|c|}{$\begin{array}{l}\text { Tufts University } \\
\text { Tuskegee Institute }\end{array}$} & 59 & 50 & 36 & & 145 \\
\hline Tuskegee Ins & ute & 60 & 58 & 57 & 50 & 225 \\
\hline \multicolumn{2}{|c|}{ Virginia-Maryland College } & 74 & 63 & & & 137 \\
\hline \multicolumn{2}{|c|}{ Washington State University } & 70 & 106 & 106 & 82 & 364 \\
\hline \multicolumn{2}{|c|}{ アメリカ登録学生総数 } & 2,239 & 2,179 & 2,057 & 1,894 & 8,369 \\
\hline \multicolumn{2}{|c|}{ ○ Guelph, University of } & 120 & 120 & 120 & 117 & 477 \\
\hline \multicolumn{2}{|c|}{ Montreal, University of } & 70 & 69 & 69 & 63 & 271 \\
\hline \multicolumn{2}{|c|}{ Saskatchewan, University of } & 72 & 67 & 63 & 67 & 269 \\
\hline \multicolumn{2}{|c|}{$\begin{array}{l}\text { カナダ登録学生総数 } \\
\text { アメリカお゙登録学生総数 }\end{array}$} & 262 & 256 & 252 & 247 & $\underline{1,017}$ \\
\hline アメリカ扰よ & :カナダ登録学生総数 & 2,501 & 2,435 & 2,309 & 2,141 & $\overline{9,386}$ \\
\hline
\end{tabular}

表 7 動物技術員（アメリカ）

\begin{tabular}{|c|c|}
\hline $\begin{array}{l}\text { 認定制度による数 } \\
\text { 卒 業 者 総 数 } \\
\text { 1981年度卒業者数 }\end{array}$ & $\begin{array}{r}54 \\
9,207 \\
997\end{array}$ \\
\hline 俸 給 （1981） & \\
\hline 給 & $\$ 7,500 \sim 11,500$ \\
\hline 験 & $\$ 7,300 \sim 14,500$ \\
\hline 表 8 1981年 & の就職状況 \\
\hline 職 & $\%$ \\
\hline 大 動 物 臨 床 & 3 \\
\hline 大小動物 臨 床 & 24 \\
\hline 小 動 物 臨 林 & 58 \\
\hline 実 験 動 物 関 倸 & 6 \\
\hline そ の 他 & 1 \\
\hline 未 定 & 8 \\
\hline
\end{tabular}

表 9 動 物 頭 数 (1979)

\begin{tabular}{|c|c|c|}
\hline 動 & 物 & 頭数(単位 100 万頭) \\
\hline \multicolumn{3}{|c|}{ 愛玩動物ならびに馬 } \\
\hline 犬 & & 42 \\
\hline$\{$ 猫 & & 31 \\
\hline 馬 & & 8 \\
\hline & 畜 & \\
\hline [畜牛 & & 111 \\
\hline$\{$ 豚 & & 67 \\
\hline 羊 & & 12 \\
\hline
\end{tabular}

これに合格して始めて一人前の獣医師になれる.しかし， 州によって NBE を必要としない州がある.

必要としない州：カリフォルニア州，コネチカット 州, フロリダ州, メリーランド州, ニュー・ジャジー 州, ニューヨーク州, オ八イオ州特よびオクラホマ州の 計 8 州. 
次の州では外国の大学を卒えた者を受け入れる規定が

ない: カンザス州, ケンタッキー州, ネブラスカ州, 二 タ州.

NBEC では 1960 年に Interstate Reporting Service (IRS) を設立した. これで州間で志願者の NBE の点数 を知る上で便利となった。

(3) アメリカにおける獣医科大学の認定：1906 年以 来，AVMA が独自に獣医学校を評価するプログラムを 発足させていたが，1946 年に Council of Education (教 育審議会) に改組して作業をすすめ，1952 年にいたって 連邦政府の Department of Education（文部省）から正 式にこの作業が依嘱された. したがって強い権限をるっ

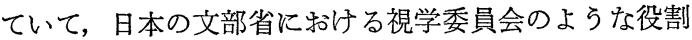
を果たしている.

認定に次のよな分類がある.

〔Full Accreditation』合格: 最小必要条件を備え, ま たは越えるもの.この分類は 7 年を越えない期間認可さ れる。

『Limited Accreditation』条件つき合格：最小必要条 件を大半，ただし全部ではないが備えるまたは越えるも の.この分類は引続き 5 年間を越えない期間指定された 条件が改善されるなら,さらに 2 年後上記の分類に移る 資格がある。

『Provisional Accreditation』 仮合格：2 年を越えない 期間指定される。

『Accreditation Withheld』 不合格.

〔Approved』合格:アメリカおよびカナダ以外の外 国大学に対し評価したもの. 最小必要条件を備え，また は越えるもの. 7 年を越光ない期間認定される.

『Approved Withheld》同様のものの不合格.

〔Reasonable Assurance』適当と保証されたもの：審 議会の計画に従って行われている新設の獣医科大学で, 将来の認定が保証されるもの．毎年更新される.

（4）アメリカにおける専門医制度 : DVM を卒えた後, さらに高度の職業過程 (Professional course) として, イ ンターン拉よびレジデントがある. インターンは 1 年,

表10 現在の認定状沉 (AVMA)

\begin{tabular}{lr}
\hline \hline 分 & 学校数 \\
\hline 合格 (Full Accreditation) & 23 \\
条件つき合格 (Limited Accreditation) & 2 \\
不合格 (Accreditation Withheld) & 0 \\
仮合格 (Provisional Accreditation) & 2 \\
適当と保証されたもの (Reasonable Assurance) & 5 \\
合格 (外国大学) (Approved) & 1 \\
\hline \multicolumn{2}{c}{ 計 }
\end{tabular}

注）現在アメリカ 29 校，カナダ 3 校扣よびオランダ 1 校が対象とされている
レジデントは最小 2 〜 年の経験を必要とする. 15 の 専門職があり, それぞれによって必要経験年数を異にし ている．これを終えた後，それぞれの専門での認定試験 がある.これに合格すると Diploma の学位を受けるこ とができる，これをえた人 (Diplomat) はそれぞれの専 門家として高く評価され，高給をもって遇される.した がってアメリカでは MS あるいは Ph. D の大学院過程 とは対照的ながら，この方面を志望する学生が多い. あ るいは Ph. D. をとった後にこれをとる者もある.ちな みに専門組織としては次のものがある.

(1) American Board of Veterinary Practitioners ( $~$ メリカ開業獣医師協会) : 経験年数 6 年を必要とする.

(2) American Board of Veterinary Toxicology (アメ リカ獣医中毒学協会): 少なくとも 2 年の指導下の研修 と 3 年の職業経験を必要とする.

(3) American College of Laboratory Animal Medicine (アメリカ実験動物医学協会) : $2 \sim 3$ 年の正式研修プロ グラムを終え，さらに 1 カ年の完全な職歴経験を有する こと.

(4) American College of Theriogenologists (アメリカ 家畜繁殖学者協会)：少なくとも5 年の野外経験を必要 とし，この中には 2 カ年の post-doctoral program のよ らな formal advanced training が必要であるか, あるい は 8 年の経験をもつもの.

(5) American College of Veterinary Anesthesiologists (アメリカ獣医麻酔医協会) : 2 カ年の在学訓練を必要と する，それに学会誌発表が義務づけられている。

(6) American College of Veterinary Internal Medicine (アメリカ獣医内科学協会)：1年のインターン, 2 年 の在学研修, 少なくとも学会誌発表 1 編の論文を必要之 する. 内科学の他にさらに心臓学, 皮膚病学抌よび神経 学の 3 専門分野が加えられている.

(7) American College of Veterinary Microbiologists (アメリカ獣医微生物学者協会)：5 カ年の研修ならびに 職歷を必要とする.

(8) American College of Veterinary Ophthalmologists (アメリカ獣医眼科医協会) : 5 カ年の研修を必要とす る.

(9) American College of Veterinary Pathologists ( $>$ メリカ獣医病理学者協会) : 5 力年の職歴, その内 3 年 は指導下研修を必要とされていたが, 最近は少なくとも 4 年の指導下研修 (Diplomates の指導下) があればよい とされている.

(10) American College of Veterinary Preventive Medicine (アメリカ獣医予防医学協会) : 少なくとも6力年 の職歴と 4 年の大学で認められた経験を必要とする.

(11) American College of Veterinary Surgeons ( $メ$ リカ獣医外科医協会)：少なくとも 5 力年, 1 年目は 
凟

rotation internship, $2 \sim 3$ 年目は residence program, 最 後の 2 年は実際的経験を必要とする.

(12) American College of Veterinary Radiology ( $ア \times$ リカ獣医放射線学協会): 最低, 審議会で認める 36 力月 の研修が必要である。

試験方法は各専門で異なるが，例党ば病理学では各試 験科目で 100 問ずつの multiple choice questions より なり，60\%以上通ると合格といらことになっている。

病理学の試験科目は，1）病理学総論，2）病理解剖 学, 3) 病理組織学, 4) 獣医病理学 (a) 大動物病理, b) 犬・猫の病理，c）実験動物, 家禽, 野生動物病理,

d）臨床病理了よりなっている.

5）所 感：カリフォルニアのデイビス・キャンパス では南国の陽光を受けて暑い位の日々であったが,ウイ スコンシン，マジソンに一飛びすると，晚秋を思わせる ようなアノラックの欲しい寒い日であった。しかし, 天 候は間もなく快復したものの，アメリカの広大さが判る よらであった、マジソンは雨人とも留学した古巣で, そ れぞれ見るもの，聞くもの，すべて懐しく，友人や知人 も多く，学部視察の公用の合間にそれぞれ旧交を暖めた 次第であった。シカゴの AVMA は最近市内より郊外の Schaumburg に移って来た由で，シカゴ down town か ら 30 マイル, O'Hare 空港から 14 マイルのところであ った. O’Hare 空港の近くのわれわれの宿舎 (Holiday Inn）からリムジンで茫漠とした郊外の Highway る飛ば して 30 分位で AVMA に着く.着いた時はらょらど朝 8 時半の開庁時であった。 AVMA は白雨の潇酒な平家

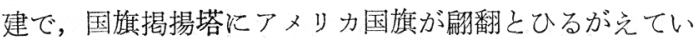
た（写真 1). 西らかじめ連絡して打いたので，女性秘 書がにこやかにわれわれを出迎えて下さった。Dr. EDWARD R. AMES（写真 2）がすべてをとりしきって 下さった，彼は北大の伊沢教授からことづてを頼れれた 魚病の紹介を書いた人その人であったが，本人は寄生虫 が専門で魚病の方には専門外とのことであった。彼から
料

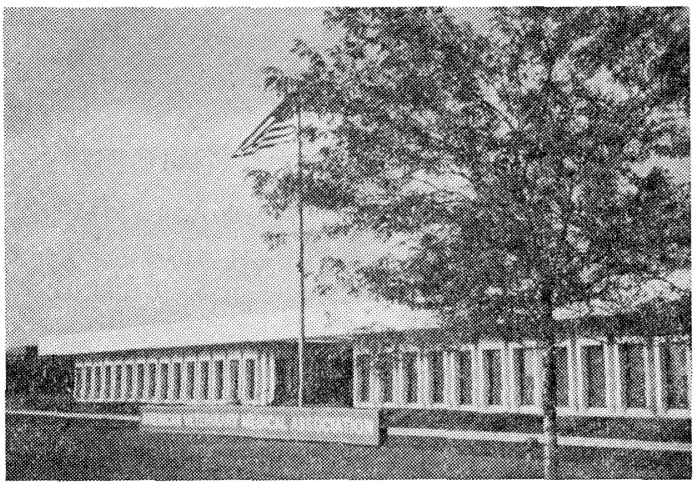

写真 1 アメリカ獣医師会 (AVMA) の建物 (930 North Meacham Rd, Schaumberg Ill.)

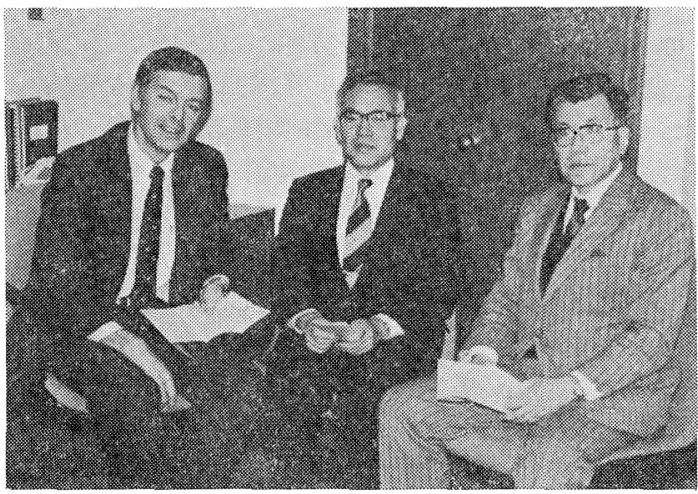

写真 2 AVMA にて（左から Dr. EDWARD R. AMEs, 笹本, 藤本)

AVMA のこと，とくに専門医制度のことなどを伺った。 非常に判りやすい, clear な発音で, ゆっくり説明して下 さったのが印象的であった，オフィス内はすべて近代的 で，明るく，事務は少数の人で能率を上げているよらに 思われた。 